\title{
KOMUNIKASI MATEMATIKA TERTULIS SISWA BERKEMAMPUAN MATEMATIKA RENDAH DALAM PEMECAHAN MASALAH SOAL HOTS BERDASARKAN JENIS KELAMIN
}

\author{
Arezqi Tunggal Asmana \\ Program Studi Pendidikan Matematika FKIP Unisda \\ Jl. Airlangga No. 3 Sukodadi Lamongan, arezqitunggal@unisda.ac.id
}

\begin{abstract}
ABSTRAK
Penelitian ini bertujuan untuk mendeskripsikan komunikasi matematika tertulis siswa berkemampuan matematika rendah dalam pemecahan masalah soal HOTS berdasarkan jenis kelamin. Penelitian ini adalah penelitian kualitatif dengan data utama tentang keakuratan, kelengkapan, dan kelancaran komunikasi matematika tertulis berupa kata-kata tertulis. Subjek penelitian adalah 2 siswa berkemampuan matematika rendah kelas XI MIPA MAN 1 Lamongan yang terdiri dari satu siswa laki-laki dan perempuan. Hasil penelitian menunjukkan bahwa adanya sedikit perbedaan komunikasi matematika tertulis siswa laki-laki dengan perempuan pada kelancaran informasi yang disampaikan.
\end{abstract}

Kata kunci: Komunikasi matematika tertulis, kemampuan matematika rendah,

pemecahan masalah, soal HOTS, jenis kelamin.

\begin{abstract}
This research aims to describe the written mathematics communication of students with low mathematical ability in solving HOTS problems based on gender. This research is a qualitative research because the main data about the accuracy, completeness, and fluency of written mathematics communication in the form of written words. The research subjects were 2 students with low mathematical ability in class XI MIPA MAN 1 Lamongan consisting of one male and female student. The results showed that there were slight differences in the written mathematics communication of male and female students in the fluency of the information conveyed.
\end{abstract}

Keywords: Written mathematics communicaton, low mathematical ability, problem solving, HOTS problem, gender.

PENDAHULUAN

Berkaitan dengan isu perkembangan pendidikan di tingkat internasional, Kurikulum 2013 dirancang dengan berbagai penyempurnaan. Salah satu penyempurnaan dilakukan pada standar isi yaitu mengurangi materi yang tidak relevan serta pendalaman dan perluasan materi yang relevan bagi peserta didik serta diperkaya dengan kebutuhan peserta didik untuk berpikir kritis dan analitis sesuai dengan standar internasional (Fanani 2018). Menurut Fanani (2018), hal itu diharapkan dapat 
membantu peserta didik untuk bernalar, kemudian mengomunikasikan meningkatkan kemampuan berpikir tingkat tinggi (Higher Order Thinking Skills/HOTS). Gunawan (2003) menjelaskan HOTS adalah proses berpikir yang mengharuskan siswa untuk memanipulasi informasi yang ada dan ideide dengan cara tertentu yang memberikan mereka pengertian dan implikasi baru.

Zohar dan Dori (2003) mengkategorikan HOTS menjadi: (1) berargumen konstruktif, (2) mengajukan pertanyaan ilmiah, (3) membuat perbandingan, (4) memecahkan masalah rumit nonalgoritma, (5) menggolongkan perbedaan pendapat, dan (6) mengidentifikasi asumsi yang tersirat. Kemudian Kemendikbud (2017) menjelaskan bahwa soal-soal HOTS merupakan instrumen pengukuran yang digunakan untuk mengukur kemampuan berpikir tingkat tinggi, yaitu kemampuan berpikir yang tidak sekadar mengingat (recall), menyatakan kembali (restate), atau merujuk tanpa melakukan pengolahan (recite).

Dalam NCTM (2000), dinyatakan bahwa standar proses dalam pembelajaran matematika, meliputi pemecahan masalah, penalaran dan pembuktian, komunikasi, koneksi, dan representasi. Menurut Hirschfeld-Cotton (2008), komunikasi membantu untuk membangun makna ketika siswa ditantang untuk berpikir dan ide-ide mereka secara lisan maupun tertulis sehingga pemahaman konseptual yang benar berkembang. Caballero dkk. (2011), komunikasi dari proses dan hasil termasuk kemampuan untuk mengirimkan secara cukup tepat bahasa lisan dan tertulis, ide-ide dan proses yang dikembangkan sehingga mereka dapat dipahami.

Bansu (dalam Agustyaningrum, 2011) menelaah komunikasi menjadi komunikasi lisan dan komunikasi tertulis. Komunikasi lisan diungkap melalui intensitas keterlibatan siswa dalam kelompok kecil selama berlangsungnya proses pembelajaran sedangkan komunikasi tertulis melalui kemampuan dan keterampilan siswa menggunakan kosakata dan notasi serta struktur untuk menyatakan gagasan dan memahaminya dalam memecahkan masalah.

Berfokus pada komunikasi tertulis, Dewi (2009) mengatakan komunikasi matematika tertulis adalah proses penyampaian ide/pikiran matematika yang diwujudkan dalam bentuk tulisan. Menurut Dewi (2009), keakuratan dan kelengkapan informasi sangat diperlukan dalam komunikasi matematika serta kelancaran yang diperlukan dalam menyampaikan informasi tersebut. Menurut Kim dan Noh (2010), secara umum ada korelasi linear 
konsisten antara pemahaman masalah terhadap proses pemecahan masalah dan keterampilan komunikasi. Selanjutnya Polya (1973) mengatakan langkah-langkah pemecahan masalah, yaitu: (1) memahami masalah; (2) membuat rencana; (3) melaksanakan rencana; dan (4) memeriksa kembali.

Menurut Asmana (2018), pada dasarnya peserta didik memiliki kemampuan matematika yang berbedabeda sehingga dimungkinkan komunikasi dalam pemecahan masalah matematika juga berbeda. Itu juga didukung beberapa hasil penelitian sebelumnya yang relevan. Salah satunya hasil penelitian oleh Venkatesh Kumar dan Karimi (2010) yang menunjukkan bahwa perbedaan pencapaian matematika dalam pemecahan masalah antara siswa laki-laki dan perempuan. Begitu pula hasil penelitian oleh Zhu (2007) yang menunjukkan bahwa terdapat perbedaan kemampuan memecahkan masalah matematika antara laki-laki dan perempuan. Menurut Nugroho dkk. (2018), secara garis besar anak laki-laki lebih baik dalam penalaran sedangkan anak perempuan lebih dalam hal ketepatan, ketelitian, kecermatan, dan keseksamaan berpikir. Hal itu dapat disimpulkan bahwa perbedaan jenis kelamin tidak lagi hanya berkaitan dengan faktor biologis saja tetapi sudah berkembang menjadi perbedaan kemampuan antara laki-laki dan perempuan (Lutfiyah dkk., 2018).

Berdasarkan hal di atas, terdapat komunikasi dan pemecahan masalah matematika serta HOTS yang sangat penting ditumbuhkembangkan di kalangan siswa. Sebagai modal awal, untuk menumbuhkembangkan komunikasi matematika tertulis sehingga dapat digunakan sebagai pedoman untuk mengupayakan pembelajaran yang lebih tepat terutama untuk peserta didik berkemampuan matematika rendah, diperlukan pengetahuan tentang komunikasi matematika tertulis siswa. Dengan meninjau perbedaaan jenis kelamin sehingga peneliti ingin mengadakan penelitian tentang "Komunikasi Matematika Tertulis Siswa Berkemampuan Matematika Rendah dalam Pemecahan Masalah Soal HOTS Berdasarkan Jenis Kelamin”.

\section{METODE PENELITIAN}

Tujuan penelitian ini untuk mendeskripsikan komunikasi matematika tertulis siswa laki-laki dan perempuan berkemampuan matematika rendah dalam pemecahan masalah. Aspek komunikasi matematika tertulis yang diamati yakni keakuratan, kelengkapan, dan kelancaran informasi yang disampaikan dalam pemecahan masalah. Informasi tersebut, yaitu menuliskan hal-hal yang diketahui 
dan ditanya, membuatkan gambar/sketsa, menggunakan aturan, melakukan perhitungan, dan membuatkan kesimpulan (Asmana, 2018). Jenis penelitian ini adalah deskriptif eksploratif yang bersifat kualitatif. Analisis dilakukan secara mendalam pada siswa berkemampuan matematika rendah untuk mendeskripsikan komunikasi matematika tertulis dalam pemecahan masalah soal HOTS dengan materi persamaan lingkaran.

Penelitian ini dilakukan di kelas XI MIPA MAN 1 Lamongan. Subjek penelitian adalah 2 siswa kelas XI MIPA MAN 1 Lamongan semester genap tahun ajaran 2018/2019 yang masing-masing terdiri dari satu siswa laki-laki dan perempuan berkemampuan matematika rendah. Penentuan subjek penelitian menggunakan Tes Kemampuan Matematika (TKM). TKM berupa 20 butir soal UNBK 2 tahun terakhir dengan materi yang sudah diajarkan dan dianggap layak oleh teman sejawat (dosen) dan guru kelas. Setiap butir soal diberi skor 5 sehingga keseluruhan jawaban memiliki skor skala 0 sampai 100 dengan kriteria penilaian untuk kemampuan matematika rendah adalah $0 \leq$ skor $<70$ (Asmana, 2018).

Instrumen utama adalah peneliti sendiri. Peneliti sebagai pengumpul data, menginterpretasi data melalui pengamatan langsung dan wawancara. Dalam penelitian ini digunakan instrumen pendukung. Instumen pendukung 1 berupa Tes Pemecahan Masalah (TPM), instrumen pendukung 2 berupa pedoman wawancara, dan instrumen pendukung 3 berupa alat perekam.

Sebelum digunakan, TPM dan pedoman wawancara divalidasi oleh teman sejawat (dosen) dan guru kelas. TPM yang valid diberikan kepada subjek penelitian sehingga diperoleh data berupa jawaban tertulis. Selanjutnya data tersebut dianalisis dengan teknik analisis data yaitu analisis isi (content analysis). Analisis isi tersebut adalah memeriksa keakuratan, kelengkapan, kelancaran jawaban tertulis yang diberikan subjek, diidentifikasi apakah jawaban yang diberikan sesuai dengan kriteria informasi yang disampaikan. Setelah itu, data diperiksa kredibilitas dengan cara triangulasi metode, ketekunan pengamatan, kecukupan referensial, dan triangulasi waktu.

\section{HASIL DAN PEMBAHASAN}

Subjek pada penelitian ini diambil 2 siswa kelas XI MIPA MAN 1 Lamongan yang disajikan pada Tabel 1.

Tabel 1. Subjek Penelitian

\begin{tabular}{lccc}
\hline $\begin{array}{c}\text { Inisial } \\
\text { Subjek }\end{array}$ & $\begin{array}{c}\text { Jenis } \\
\text { Kelamin }\end{array}$ & $\begin{array}{c}\text { Kemampuan } \\
\text { Matematika }\end{array}$ & $\begin{array}{c}\text { Kode } \\
\text { Subjek }\end{array}$ \\
\hline MRD & L & Rendah & LR \\
NNJ & P & Rendah & SR \\
\hline
\end{tabular}


Kedua subjek penelitian di atas diberikan TPM 1 pada pengambilan data pertama dan TPM 2 pada pengambilan data kedua. TPM tersebut sebagai berikut.

\section{TPM 1:}

Suatu gunung berapi meletus sehingga mengakibatkan gempa. Salah satu episentrum (titik pusat) dari suatu gempa terletak pada koordinat peta $(5,3)$ dalam $\mathrm{km}$. Gempa tersebut memiliki radius $36 \mathrm{~km}$. Jika orang $A$ memiliki koordinat lokasi di $(26,31)$ dan orang $B$ di $(21,33)$ maka bagaimanakah perbedaan dampak gempa terhadap kedua orang tersebut?

\section{TPM 2:}

Suatu gunung berapi meletus sehingga mengakibatkan gempa. Salah satu episentrum (titik pusat) dari suatu gempa terletak pada koordinat peta $(2,7)$ dalam $\mathrm{km}$. Gempa tersebut memiliki radius $53 \mathrm{~km}$. Jika orang $C$ memiliki koordinat lokasi di $(16,55)$ dan orang $D$ di $(47,31)$ maka bagaimanakah perbedaan dampak gempa terhadap kedua orang tersebut?

Hasil analisis data yang diperoleh sebagai berikut.

\section{Komunikasi Matematika Tertulis}

\section{Subjek LR}

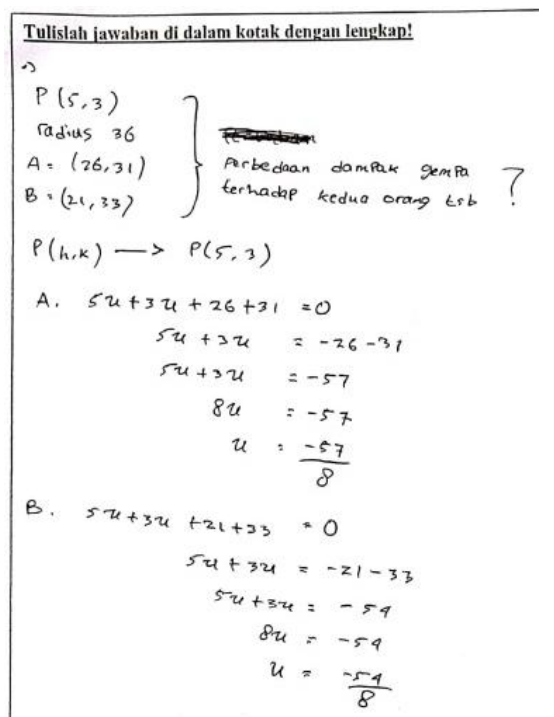

Gambar 1. KMT LR untuk TPM 1
Berdasarkan Gambar 1, keakuratan dan kelengkapan komunikasi matematika tertulis LR menunjukkan hanya akurat dan lengkap untuk menuliskan hal-hal yang diketahui dan ditanya. Hal itu sesuai untuk hasil TPM 2 yang disajikan pada Gambar 2.

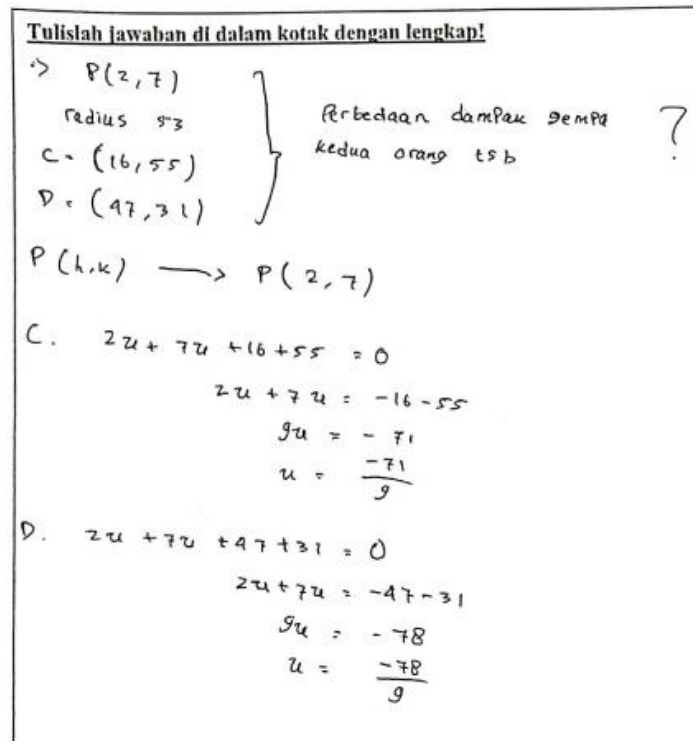

\section{Gambar 2. KMT LR untuk TPM 2}

Berdasarkan Gambar 1 dan 2, meskipun LR melakukan perhitungan tetapi perhitungan tersebut tidak akurat. Hal itu sesuai dengan jawaban pada saat wawancara. Berikut cuplikan wawancara pada langkah melakukan perhitungan.

$\begin{array}{ll}\mathrm{P} & : \text { Apakah kamu melakukan perhitungan? } \\ \mathrm{LR} & : \text { Ya, ini pak. (Sambil menunjuk hasil } \\ & \text { pekerjaan) } \\ \mathrm{P} & : \text { Ini dari mana asalnya? } \\ & \text { Ada } 2 x+7 x+16+55=0 \ldots \\ \mathrm{LR} & : \text { Kan ini dari lokasi gempanya ada } 2 \text { dan } 7 \\ & \quad \text { lalu } 16 \text { dan } 55 \text { dari orang } C . \\ \mathrm{P} & : \text { Lalu kenapa sama dengan nol? } \\ \mathrm{LR} & : \text { Ya kan biasanya kayak gini dikasih sama } \\ & \text { dengan nol. } \\ \mathrm{P} & : \text { Kenapa seperti itu? } \\ \mathrm{LR} & : \text { Gak tau pak. Lupa pak. } \\ \mathrm{P} & : \text { Kenapa mencari x lagi yang bawah ini? } \\ \mathrm{LR} & : \text { Gak tau pak. Saya samakan yang atas. }\end{array}$


Berdasarkan Gambar 1 dan 2

serta hasil wawancara, kelancaran komunikasi matematika tertulis LR menunjukkan lancar untuk menuliskan hal-hal yang diketahui dan ditanya serta melakukan perhitungan. Meskipun demikian, LR menunjukkan tidak lancar untuk menyampaikan informasi sampai tujuan akhir dengan batas waktu yang diberikan. Hal ini sedikit berbeda dengan hasil penelitian Sugiarto dan Budiarto (2014) yang menunjukkan bahwa komunikasi matematika tertulis siswa berkemampuan matematika rendah adalah akurat dan lengkap untuk menuliskan halhal yang diketahui dan ditanya serta membuatkan gambar/sketsa sedangkan dalam penelitian ini hanya akurat dan lengkap untuk menuliskan hal-hal yang diketahui dan ditanya.

\section{Komunikasi Matematika Tertulis Subjek PR}

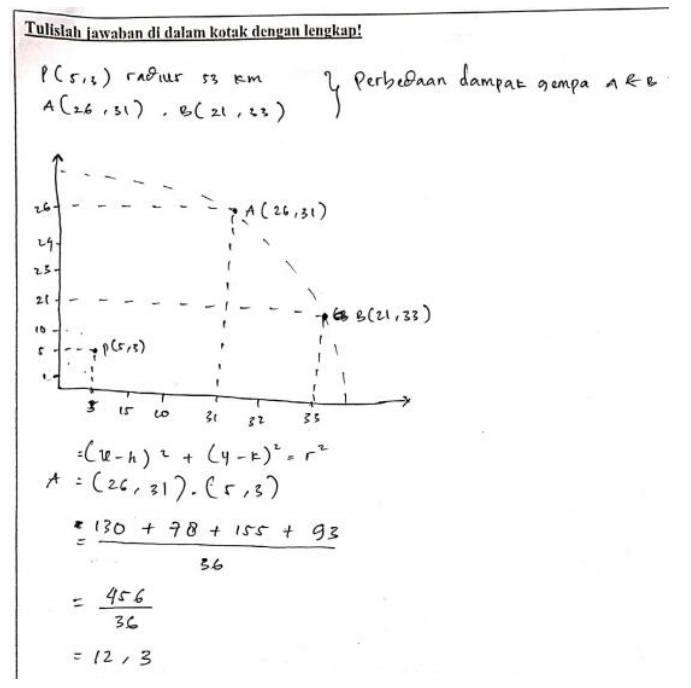

Gambar 3. KMT PR untuk TPM 1
Berdasarkan Gambar 3, keakuratan dan kelengkapan komunikasi matematika tertulis PR menunjukkan hanya akurat dan lengkap untuk menuliskan hal-hal yang diketahui dan ditanya. Hal itu sesuai untuk hasil TPM 2 yang disajikan pada Gambar 4.

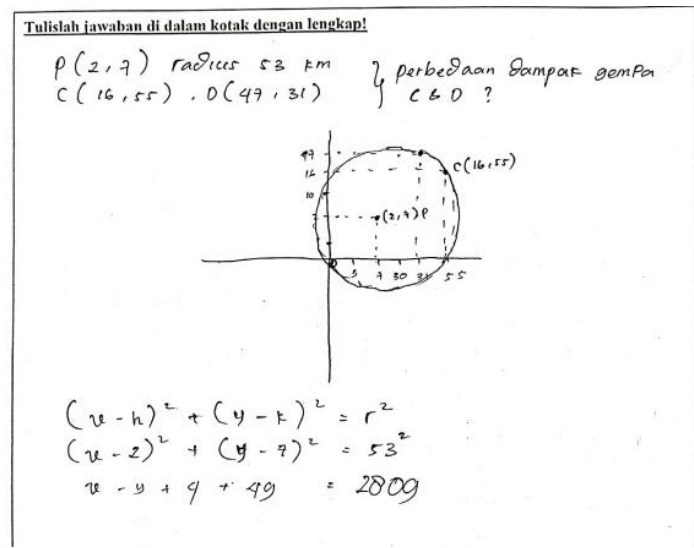

Gambar 4. KMT PR untuk TPM 2

Berdasarkan Gambar 3 dan 4, meskipun PR membuatkan gambar/sketsa, menggunakan aturan, dan melakukan perhitungan tetapi hal tersebut tidak akurat dan lengkap. Hal itu sesuai dengan jawaban pada saat wawancara. Cuplikan wawancara tersebut sebagai berikut.

\begin{tabular}{|c|c|}
\hline$P$ & : Apakah kamu membuatkan gambar/sketsa? \\
\hline PR & : Ya. \\
\hline $\mathrm{P}$ & : Seperti apa itu gambarnya? \\
\hline PR & : Persamaan lingkaran. \\
\hline $\mathrm{P}$ & : Apa saja yang ada di gambar itu? \\
\hline PR & $\begin{array}{l}\text { : Gimana pak?(Diam sejenak sambil } \\
\text { menunjukkan ekspresi bingung) }\end{array}$ \\
\hline $\mathrm{P}$ & : Jelaskan apa maksud yang ada di gambar! \\
\hline PR & $\begin{array}{l}\text { : Ini kan titik pusatnya }(2,7) \text {. Yang ini }(16,5) \\
\text { koordinat lokasi C... (Sambil menjukkan jari } \\
\text { ke jawaban) }\end{array}$ \\
\hline $\mathrm{P}$ & $\begin{array}{l}\text { : Apakah dari gambar sudah bisa diketahui } \\
\text { jawabannya? }\end{array}$ \\
\hline PR & : Belum. \\
\hline $\mathrm{P}$ & $\begin{array}{l}\text { : Apakah kamu menggunakan aturan? } \\
\text { Rumus? }\end{array}$ \\
\hline PR & : Iya. \\
\hline
\end{tabular}




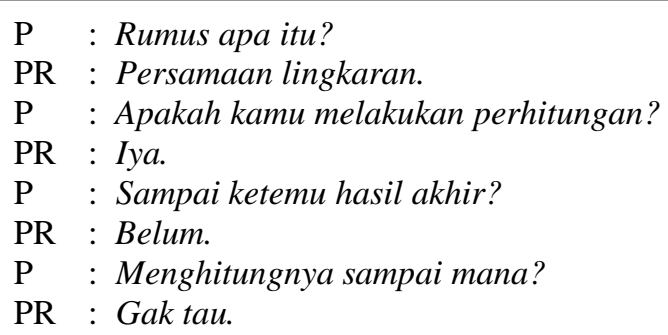

Berdasarkan Gambar 3 dan 4 serta hasil wawancara, kelancaran komunikasi matematika tertulis PR menunjukkan hanya tidak lancar untuk membuatkan kesimpulan. Meskipun demikian, PR menunjukkan tidak lancar untuk menyampaikan informasi sampai tujuan akhir dengan batas waktu yang diberikan. Itu berbeda sedikit dengan hasil penelitian Isroil dkk. (2017) yang menunjukkan bahwa siswa berkemampuan matematika rendah salah melakukan perhitungan dan mendapatkan kesimpulan yang tidak benar sedangkan hasil penelitian peneliti menunjukkan tidak membuatkan kesimpulan.

\section{KESIMPULAN DAN SARAN}

Berdasarkan hasil analisis data dan pembahasan dapat disimpulkan komunikasi matematika tertulis siswa laki-laki dan perempuan berkemampuan matematika rendah tentang keakuratan, kelengkapan, dan kelancaran komunikasi matematika tertulis dengan informasi yang disampaikan. Informasi tersebut, yaitu menuliskan hal-hal yang diketahui dan ditanya, membuatkan gambar/sketsa, menggunakan aturan, melakukan perhitungan, dan membuatkan kesimpulan.

Pada keakuratan dan kelengkapan komunikasi matematika tertulis siswa laki-laki dan perempuan berkemampuan matematika rendah adalah hanya akurat dan lengkap untuk menuliskan hal-hal yang diketahui dan ditanya. Kelancaran komunikasi matematika tertulis siswa laki-laki dan perempuan berkemampuan matematika rendah adalah tidak lancar. Hasil itu menunjukkan adanya sedikit perbedaan komunikasi matematika tertulis untuk siswa laki-laki dan perempuan berkemampuan matematika rendah pada kelancaran informasi yang disampaikan.

Penelitian ini hanya difokuskan pada komunikasi matematika tertulis siswa lakilaki dan perempuan berkemampuan matematika rendah dalam pemecahan masalah soal HOTS. Selanjutnya disarankan melakukan penelitian lanjutan tentang komunikasi matematika tertulis berdasarkan faktor lain, memperluas subjek penelitian, materi soal yang lain, dan komunikasi matematika lisan.

\section{DAFTAR PUSTAKA}

Agustyaningrum, N. (2011). Implementasi Model Pembelajaran Learning Cycle 5E Untuk Meningkatkan Kemampuan Komunikasi Matematis Siswa Kelas IX B SMP Negeri 2 
Sleman. Prosiding,

http://eprints.uny.ac.id/7389/1/p-

34.pdf

Asmana, A. T. (2018). Profil Komunikasi

Matematika Tertulis dalam

Pemecahan Masalah Matematika di

SMP Ditinjau dari Kemampuan

Matematika. INSPIRAMATIKA:

Jurnal Inovasi Pendidikan dan

Pembelajaran Matematika, 4(1), 1-

12.

Caballero, A., Blanco, L. J., dan Guerrero, E. (2011). Problem solving and emotional education in initial primary teacher education. Eurasia Journal of Mathematics, Science and Technology Education, 7(4), 281-292.

https://doi.org/10.12973/ejmste/752 06

Dewi, I. (2009). Profil Komunikasi Matematika Mahasiswa Calon Guru Ditinjau dari Perbedaan Jenis Kelamin. Disertasi tidak diterbitkan. Surabaya: PPs Universitas Negeri Surabaya.

Fanani, M. Z. (2018). Strategi Pengembangan Soal Higher Order Thinking Skill (HOTS) dalam Kurikulum 2013. Edudeena, 2(1), 57-56.

https://jurnal.iainkediri.ac.id/index.p hp/edudeena/article/download/582/4 55
. Gunawan, A. W. (2003). Genius Learning Strategy: Petunjuk Praktis untuk Menerapkan Accelerated Learning. Jakarta: Gramedia Pustaka Utama.

Hirschfeld-Cotton, K. (2008). Mathematical Communication, Conceptual Understanding, and Students' Attitudes Toward Mathematics. Action Research Projects (Paper 4). http://digitalcommons.unl.edu/cgi/vi eviewcont.cgi?article $=1011 \&$ contex $\mathrm{t}=$ mathmidactionresearch.

Isroil, A., Budayasa, I. K., dan Masriyah. (2017). Profil Berpikir Siswa SMP dalam Menyelesaikan Masalah Matematika Ditinjau dari Kemampuan Matematika. Jurnal Review Pembelajaran Matematika, 2(2), 93-105. http://jrpm.uinsby.ac.id/index.php/jr pm/article/download/34/31

Kemendikbud. (2017). Modul Penyusunan Soal Higher Order Thinking Skill (HOTS). Jakarta: Direktorat Pembinaan SMA Ditjen Pendidikan Dasar dan Menengah.

Kim, M. K., dan Noh, S. (2010). Alternative mathematics assessment: A case study of the development of descriptive problems for elementary school in Korea. Eurasia Journal of Mathematics, Science and 
Technology Education, 6(3), 173186.

http://www.ejmste.com/v6n3/eurasi

a_v6n3_kim.pdf

Lutfiyah, S. M., Kartinah, dan Rubowo,

M. R. (2018). Profil Pemahaman

Konsep Siswa Laki-laki dalam

Pemecahan Masalah Matematika

Menurut Tahapan Polya. Makalah disajikan pada Seminar Nasional Matematika dan Pendidikan $\left(3^{\text {th }}\right.$ SENATIK), Semarang, 11 Agustus 2018.

http://prosiding.upgris.ac.id/index.p hp/senatik2018/senatik18/paper/vie wFile/2855/2682

NCTM. (2000). Principles and Standards for School Mathematics. School Science and Mathematics (Vol. 47). https://doi.org/10.1111/j.19498594.2001.tb17957.x

Nugroho, M., Setyawati, R. D., dan Sutrisno. (2018). Profil Kemampuan Siswa Laki-laki dalam Memecahkan Masalah Relasi Fungsi. Makalah disajikan pada Seminar Nasional Matematika dan Pendidikan $\left(3^{\text {th }}\right.$ SENATIK), Semarang, 11 Agustus 2018. http://prosiding.upgris.ac.id/index.p hp/senatik2018/senatik18/paper/vie wFile/2845/2672

Polya, G. (1973). How to Solve It. Princeton University Press (Vol. 30).

https://doi.org/10.2307/3609122

Venkatesh Kumar, G. dan Karimi, A. (2010). Mathematics anxiety, mathematics performance and overall academic performance in high school students. Journal of the Indian Academy of Applied Psychology, 36(1), 147-150. http://search.ebscohost.com/login.as px?direct $=$ true $\& d b=$ psyh $\& A N=201$ 0-03566-016\&site=ehost-live

Zhu, Z. (2007). Gender differences in mathematical problem solving patterns: A review of literature. International Education, 8(2), 187203.

Zohar, A. dan Dori, Y. J. (2003). Higher order thinking skills and low achieving students: Are they mutually exclusive. The Journal of The Learning Sciences, 12(2), 145181. 